\title{
Open Educational Resources: Enabling universal education
}

\author{
Tom Caswell, Shelley Henson, Marion Jensen, and David Wiley \\ The Center for Open and Sustainable Learning \\ Utah State University
}

\begin{abstract}
The role of distance education is shifting. Traditionally distance education was limited in the number of people served because of production, reproduction, and distribution costs. Today, while it still costs the university time and money to produce a course, technology has made it such that reproduction costs are almost non-existent. This shift has significant implications, and allows distance educators to play an important role in the fulfillment of the promise of the right to universal education. At little or no cost, universities can make their content available to millions. This content has the potential to substantially improve the quality of life of learners around the world. New distance education technologies, such as OpenCourseWares, act as enablers to achieving the universal right to education. These technologies, and the associated changes in the cost of providing access to education, change distance education's role from one of classroom alternative to one of social transformer.
\end{abstract}

Keywords: OpenCourseWare; distance education; access; new technologies

\section{Introduction}

The role of distance education is changing. Traditionally distance education was limited in the number of people served because of production, reproduction, distribution, and communication costs. In the past, schools spent resources to produce a course, and then spent additional resources to reproduce the course, and send it to students. While it still costs a university time and money to produce a course, technology has made reproduction and distribution costs almost non-existent. A course can be sent electronically, or placed online, and any number of students can access the material. This marked decrease in costs has significant implications and allows distance educators to play an important role in the fulfillment of the promise of the right to universal education. At relatively little additional cost, universities can make their content available to millions. This content has the potential to substantially improve the quality of life of learners around the world.

Article 26 of the Universal Declaration of Human Rights declares that everyone has the right to education, and that "technical and professional education shall be made generally available (United Nations, 1948)." The movement to make this happen has already begun. 
OpenCourseWares are online open access collections of educational materials used in courses at universities such as the Massachusetts Institute of Technology (MIT), the Open University, Johns Hopkins, Kyoto University, Notre Dame, and Korea University. Currently, over 2,500 open access courses are freely available from over 200 universities worldwide. And additional higher education institutions are launching OpenCourseWare-style projects regularly.

New distance education technologies, legal practices, and philosophies, such as OpenCourseWares, act as enablers to achieving the universal right to education. The Open Educational Resources (OER) movement is a technology-empowered effort to create and share educational content on a global level. This paper will explore these kinds of endeavors, and how they can move distance education's role from one of classroom alternative to one of social transformer.

\section{OpenCourseWare Overview}

On April 4, 2001, Massachusetts Institute of Technology's President Charles M. Vest announced that the MIT would make the materials for nearly all its courses freely available on the Internet over the next ten years. This new program would be known as MIT OpenCourseWare (MIT, 2001). MIT OpenCourseWare has a dual mission: First, to provide free access to virtually all MIT course materials for educators, students, and individual learners around the world. Second, to extend the reach and impact of MIT OCW and the OpenCourseWare concept (MIT, 2006).

OpenCourseWare (OCW), an initiative within the Open Educational Resources movement, finds its origins in the free software movement. In 1983, Richard Stallman announced the foundation of the GNU project housed within the MIT Artificial Intelligence Lab. The purpose of this project was to build Unix-compatible software and share it freely with anyone. His plan called for community contributions in the form of programming support, hardware, and even money to hire programmers. This open, community approach became increasingly prevalent with software developers. In 1991, Linus Torvalds used GNU tools to develop Linux, now a popular open source operating system built on the same open principles and licensed under a GNU General Public License (GPL) (Wikipedia, 2007b).

In 1998, David Wiley announced the first open content license. This license was based on the premise that educational content should be freely developed and shared "in a spirit similar to that of free and open software" (Wiley, 2003). The idea that content should be free and openly available became popular quickly. Stallman announced the GNU Free Documentation License (GNU FDL) in 2000. In 2002, Creative Commons released their first set of copyright licenses that helped content producers license their content for reuse (Creative Commons, 2007a).

By the time MIT went live with 50 courses in a pilot version of OpenCourseWare in 2002 (MIT, 2006), Wikipedia had been running for a year, the Internet Archive had been up and running for seven years, and Project Gutenberg had over twenty years of public domain, communitycontributed content in its library (Wikipedia, 2007a). These and other projects became core to the Open Educational Resources movement. 
The purpose of the Open Educational Resources movement is to provide open access to high quality digital educational materials. There is broad participation by universities, private organizations, and others. Projects include the Internet Archive (see http://internetarchive.org), Project Gutenberg (see http://gutenberg.org), Wikipedia (see http://wikipedia.com), Creative Commons (see http://creativecommons.org), Sun Microsystems Global Education Learning Community (see https://edu-gelc.dev.java.net/nonav/index.html) and, as is the focus of this article, the OpenCourseWare Consortium (see http://ocwconsortium.org). The list of participating organizations grows every year as the principles of openness spread.

Hewlett (2005) describes OpenCourseWare as an initiative in the Open Educational Resources movement. OpenCourseWare is one way that distance education can support equal access to education. An OpenCourseWare is a digital collection of freely available educational materials organized as courses (OCW Consortium, 2007). OCW materials may include a professor's lecture notes, video of course lectures, exams, reading materials, or any other resources used to teach courses at universities and institutions worldwide.

OpenCourseWare was conceived at MIT by a committee of faculty, students, and administrators. Their charge was to provide the university with guidance regarding how MIT should position itself in the budding online distance education environment. At the time of the dot.com boom, many people felt that tuition and fees from online education would fill university coffers. The MIT committee's recommendations, however, were unexpected. They recommended freely and openly sharing the materials used to teach courses at MIT. In launching this visionary initiative, MIT set the stage to enable universities and organizations to extend the reach and opportunities afforded by teaching and learning to the world at large. Through OCW projects, universities can share and contribute their knowledge and expertise in an open and easily accessible manner.

There is growing momentum among higher education institutions to participate in this "open" movement. As of November 2007, over 160 higher education institutions and affiliated organizations who have committed to begin an OCW website and openly share 10 courses. The 10 course commitment is a requirement to be able to join the OpenCourseWare Consortium, an organization established to assist the OCW movement. Currently, there are over 100 member institutions and associated organizations around the world (see Figure 1). There are currently 28 universities with live sites (OCW Consortium, 2007). On November 28, 2007, the MIT community celebrated a major milestone for OpenCourseWare. This event "marked the publication of core teaching materials including syllabi, lecture notes, assignments and exams from virtually all MIT courses, 1,800 in total. The site includes voluntary contributions from $90 \%$ of faculty (MIT, 2007a)." Figure 1 is on the next page. 
Figure 1. Image of the top portion of the OCW Consortium page of participants

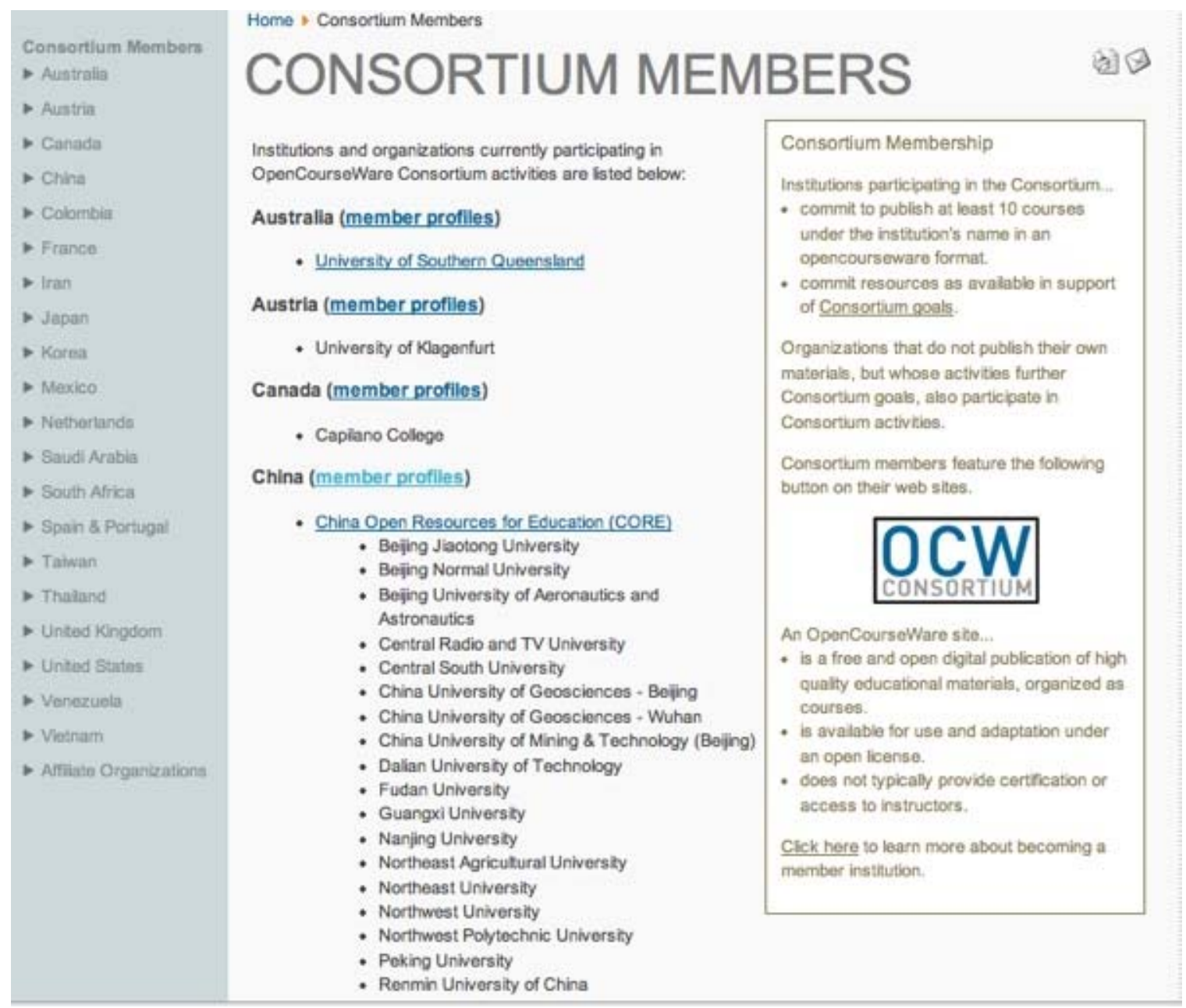

Other schools' open educational resource initiatives are seeing a large amount of traffic. The Open University of the United Kingdom's "Open Content Initiative" has been online for just over a year and has had over one million visitors come to their site.

MIT and other early adopters started their OCW site with seed money from grants and private funding. Governments now help with the funding of OCW projects. In 2007, Utah became the first state in the United States to provide public money to fund an OCW. The Utah State legislature gave seven state schools money to produce courses for the Utah OpenCourseWare Alliance (Utah OpenCourseWare Alliance, 2007).

OpenCourseWare reaches more learners. Utah State University's OCW (see http://ocw.usu.edu) has a number of courses on biological irrigation engineering with detailed specifications regarding the design and construction of irrigation systems. These materials can be accessed by rural farmers in Azerbaijan looking for a better way to get water to their crops. The Open University of the Netherlands has shared a course on computer science designed for self-paced learning that can be used by a self-taught network administrator in Malaysia. Courses from Notre Dame's Peace Studies department can be easily accessed by university faculty and students in Brazil. Rogelio Morales of Venezuela said, "This has allowed a lot of people to access this 
information who might otherwise have been unable to do so. OCW has enormous potential for our country" (MIT, 2007b).

There are many institutions and businesses, and even individuals, creating OCW content. At 1,800 courses and counting (MIT, 2007a) MIT boasts the largest collection of OCW courses, but the number of courses from other participating schools has now surpassed the number of courses offered by MIT. In the United States, the Johns Hopkins Bloomberg School of Public Health, Tufts University, University of Notre Dame, and Utah State University are all active participants, with more than a dozen other schools in the initial stages of launching an OpenCourseWare. Outside the United States, there are approximately 20 countries with schools participating in the movement, including China, Vietnam, Spain, South Africa, Saudi Arabia, France, Japan, and Korea.

Other institutions are sharing their OER content, though not calling what they do OpenCourseWare. Examples of other types of OERs include the iTunes audio lecture series from the University of California at Berkley. Another is the Connexions project at Rice University, which posts educational content online, though not always in course format.

At least one business has entered the OCW arena by providing training and other educational materials under a Creative Commons license. Through its "Novell OpenCourseWare" site, Novell has published documentation, a knowledge base, and training materials (see Figure 2).

Figure 2. Image of Novell's OpenCourseWare Site

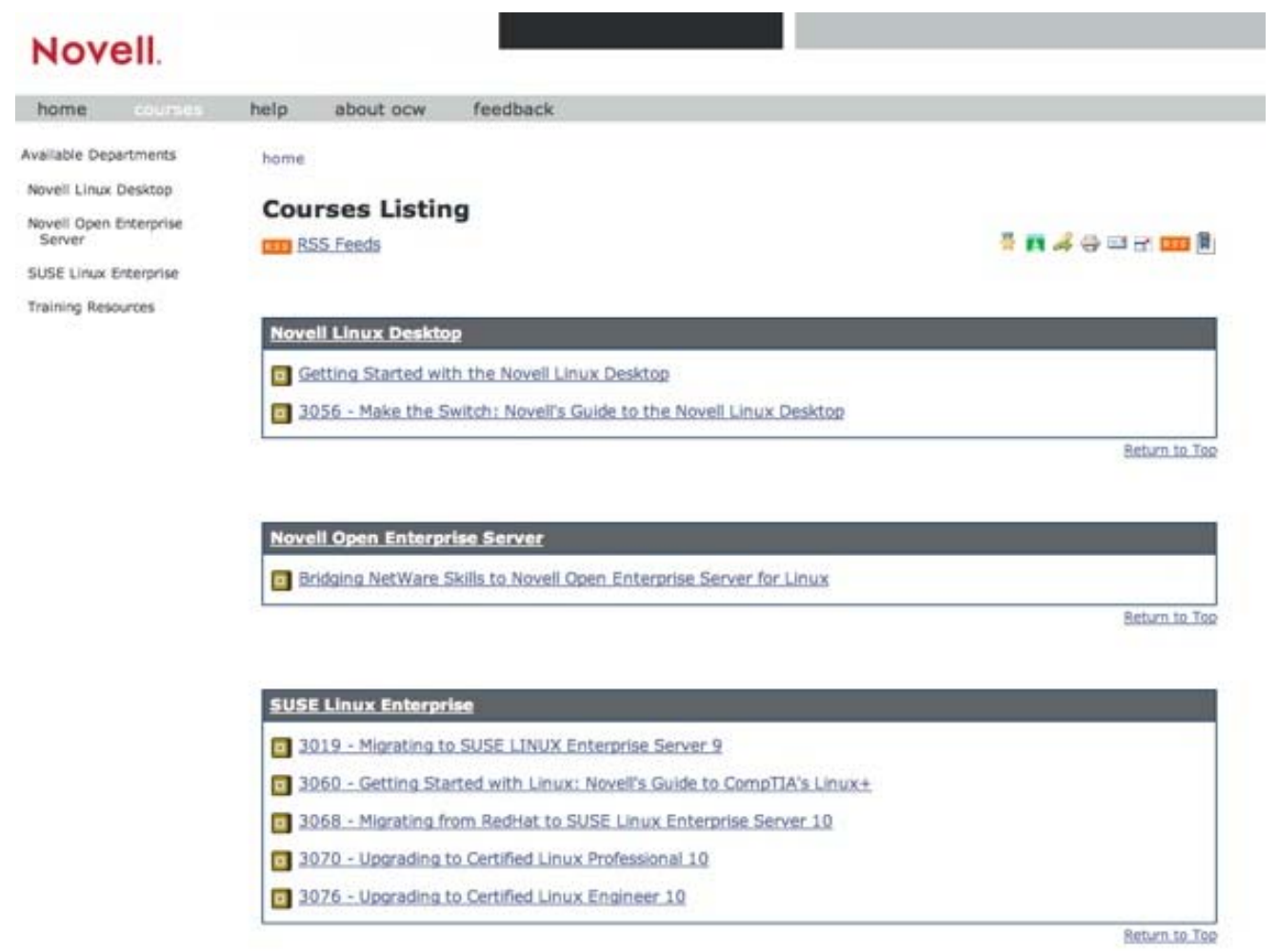




\section{Creative Commons}

The production of open educational resources goes beyond even the organizations that create the materials. There are thousands of producers involved in the open education movement, though many of them do it without realizing it. Every time material is created and licensed under a Creative Commons (see http://creativecommons.org) or other "open" license, there is potential for that material to be used in an educational setting. Many of the images found in Utah State University's OpenCourseWare courses were found on the Flickr image website using the Creative Commons search. These images were originally taken for some other purpose, but because the creator chose a Creative Commons license, they were easily and legally re-used on an OpenCourseWare site. Project Gutenberg, a collection of over 20,000 public domain books, is another example of how open educational resources can be re-purposed for education. Two public domain plays from the readings section of the Utah State University OCW Theater Arts course have been made available in their entirety in this way. Creative Commons and other open licenses allow material the potential to be readily re-used in an OpenCourseWare course or other educational product. "Creative Commons defines the spectrum of possibilities between full copyright - all rights reserved - and the public domain - no rights reserved:" (Creative Commons, 2007b). In most cases, the only restrictions are that the original producer be given attribution, that the work may not be used for commercial purposes, and that adaptations of the work be shared with the community.

Materials in OCW collections are not only freely available, but their reuse and adaptation is encouraged. Many of these resources are licensed under a Creative Commons license allowing for distribution, remix, and reuse of materials. The Open University of the UK (see http://open.ac.uk) recently announced a competition to encourage users to remix content available on their site. And the Center for Open and Sustainable Learning (see http://cosl.usu.edu) and the Connexions project at Rice University (see http://cnx.org/) have developed technologies that leverage open licenses and encourage users to build and share custom collections of open materials. The materials produced for OpenCourseWare collections are meant to be used and re-used by selflearners, students, and faculty alike.

\section{Support for New OCW Partners}

Providing these self-learners, students, and faculty with OpenCourseWare materials from a university is not as difficult as it might seem. It starts with a conversation about OpenCourseWare that includes administrators and key faculty. Finding faculty who are willing to share their course materials is crucial. Once they have identified one or two courses they are willing to share in an open access format, the process can begin. Even a small group of enthusiastic faculty and administrators can provide a strong starting point. They can help build support for OCW and give it a greater chance for success.

Once key faculty are willing to share their content have been identified, a logical next step is to set-up an OpenCourseWare pilot. Organizations, such as the Center for Open and Sustainable Learning, have provided resources such as software and support materials to explain what OCW is and why institutions should participate. An eduCommons demo site is available as a sort of "sandbox" for those interested in trying the software before making a decision about how to host their OpenCourseWare (see http://demo.educommons.usu.edu). The eduCommons software is

designed to make implementing and managing an OpenCourseWare project as simple and painfree as possible. eduCommons makes it easy to get teaching materials into a repository, tag the 
materials with metadata, and track each individual bit of teaching material through a copyright clearance, quality assurance, and publication process. The William and Flora Hewlett Foundation generously funds the development of eduCommons, and the Center for Open and Sustainable Learning makes the software available completely free of charge. Support is available as questions arise.

The actual process of managing OpenCourseWare production can be set up many different ways. Often it can be integrated in an institution's existing faculty technology support or media center. Most successful OpenCourseWares have staff dedicated to handling the technical process of converting course content into OCW content. This can reduce the time commitment required of faculty to just a few hours, including an initial meeting to obtain existing course content and a follow-up meeting to obtain final approval once the OCW course has been created. Minimizing the time required of faculty to create an OCW course increases the likelihood that faculty will choose to participate. Other successful OpenCourseWares use the course conversion and redesign process as service opportunities for students looking for capstone projects.

Each institution will need to develop its own policies and standards. This includes course design standards, intellectual property policies, and faculty release agreements. (Samples of these may be obtained free of charge from COSL.) The first few OCW courses published by an institution will serve several purposes. They will help those involved to gain an understanding of the software, how to deal with intellectual property, as well as the overall OCW course publication process. These initial courses, however, can also be good internal marketing tools, useful when approaching other faculty about adding their course materials to the institution's OpenCourseWare. The first few OCW courses and the new OCW site can help start conversations with new, interested faculty. And, finally, once additional interest has been sparked, it may be necessary to pull together more resources to support the growing OCW project. These resources will likely take the form of people, time, and possibly technical infrastructure. This is an iterative process that will continue as the OCW project grows and takes on more meaning and importance within the institution, and as potential participants come to more clearly understand the benefits and possible challenges of an OpenCourseWare project.

\section{Benefits and Challenges}

There are several reasons a school, business, or individual would license their material to be used or re-used in an open manner. Wiley (2006) describes one such reason:

We believe that all human beings are endowed with a capacity to learn, improve, and progress. Educational opportunity is the mechanism by which we fulfill that capacity. Therefore, free and open access to educational opportunity is a basic human right. When educational materials can be electronically copied and transferred around the world at almost no cost, we have a greater ethical obligation than ever before to increase the reach of opportunity. When people can connect with others nearby or in distant lands at almost no cost to ask questions, give answers, and exchange ideas, the moral imperative to meaningfully enable these opportunities weighs profoundly. We cannot in good conscience allow this poverty of educational opportunity to continue when educational provisions are so plentiful, and when their duplication and distribution costs so little. († 1)

MIT's mission statement echoes this sentiment. Their goal is "to advance knowledge and educate students in science, technology, and other areas of scholarship that will best serve the nation and 
the world in the 21st century" (see http://ocw.mit.edu/OcwWeb/Global/AboutOCW/ourstory.htm). If educational materials can bring people out of poverty, and information can now be copied and shared with greater ease, there is a moral obligation to do so. Information should be shared, because it is the right thing to do.

There are other benefits that come when a university shares their content, however. In a recent survey (MIT, 2006) MIT found 35 percent of Fall 2005 entering freshmen aware of MIT OCW prior to attending MIT indicated the site was a significant or very significant influence on their choice of school. Seventy-one percent of all MIT students (undergraduate and graduate) made use of MIT OCW in their research and studies. Ninety-six percent of MIT students using the MIT OCW site reported it has had a positive or extremely positive impact on their student experience. Finally, 40 percent of MIT faculty using MIT OCW reported that the site is a helpful tool in revising/ updating courses, and 38 percent use the site for advising students. MIT's OCW increased the interest of potential students to apply for MIT, and helped students at their school in both advising, and course work.

Aside from helping administration and students, OpenCourseWare is also beneficial to faculty members. Faculty members can share their work, their research findings, and their course structure with others in their field. Other faculty members can use and re-use their material, building upon the work others have begun. One example of this is Brett Shelton, a faculty member at Utah State University. Dr. Shelton developed an OCW course on instructional games. The course consisted of his content, as well as content generated by his students in the class. Dr. Shelton's OCW course appears fourth on a Google search for the phrase 'instructional games'. This has allowed others to know of Dr. Shelton's interest and expertise in instructional games.

Yue, Yang, Ding, and Chen (2004) discussed the increasing use of OpenCourseWare content for Computer Science education. They described the process Computer Science educators go through to pull raw content from OpenCourseWare sites as they build courses for their own students. The problems of using search engine results instead of OCW content include the lack of detail regarding copyright permissions for search engine results, the uneven quality of resources found on search engines, and how results may be too scattered and disparate to be integrated into a course. When dealing with content from an OCW site, they suggested a spectrum of approaches that runs from directly linking to the OCW content to cutting and pasting the content into a local version of the remixed course. Directly linking to content is simple, but leaves educators with no ability to customize the content for their students. On the other hand, cutting and pasting content can lead to complications. For example, if content on one site is licensed under a Creative Commons Attribution license, and content from another site is licensed under the GNU FDL, it is possible that the license requirements are in conflict with one another. This forces the educator to pay attention to a layer of their instruction beyond what is simply pedagogically sound. Regardless, Yue and colleagues suggest that the benefits of OCW materials outweigh the challenges for educators.

Kirkpatrick (2006) describes the challenges for institutions looking to support OCW sites. One challenge is dealing with intellectual property. Most faculty members in the United States use excerpts from copyrighted materials under the fragile notion of "Fair Use". This works because their content is provided only to enrolled students under controlled conditions such as user authentication. When that same course is meant to be shared openly online, however, "Fair Use" ceases to apply. All content placed online must be cleared for copyright violations. MIT's original model was to contact publishers to gain permission to openly publish materials. Only 20 percent of initial requests were granted from publishers. They modified their approach, and now 
Open Educational Resources: Enabling universal education

Caswell, Henson, Jensen, \& Wiley

recommend only pursuing permission for critical content pieces. Instead, they produce replacement content or, if it is instructionally unnecessary, remove the content altogether. This, however, is not the only challenge institutions face regarding copyright. Many institutions have unclear guidelines regarding who actually owns the copyright, that is, is it the faculty member or the institution? This policy question can create a quagmire of faculty/ administration committee struggles. MIT and Utah State University deal with this by providing a faculty release agreement that indicates that the copyright is retained by the faculty member who grants the institution rights to publish the content. Nearly all content coming out of OCWs is licensed under Creative Commons licenses, but as is true with traditional copyright, there is no guarantee that the user will comply with (or even understand) license requirements.

As with any institutional initiative, OCW can be difficult to fund. To date, private foundations such as the William and Flora Hewlett Foundation and the Andrew W. Mellon Foundation have provided the bulk of the funding for OCW initiatives. There is only so much grant money to go around, however. Costs associated with OCW course development include software, hardware, hosting costs, and human resources. Open source software, like eduCommons, can make projects less expensive. Some schools, such as the Open University of the UK opt to use other open source software such as the Moodle learning management system (see http://moodle.org). Downes (2007) describes a number of financial models that can be used to help sustain OCW projects. These include a sponsorship model, support from governmental agencies, donations, endowments, and other potential models. Insuring the sustainability of these projects moving forward is of critical importance.

\section{Sustaining OpenCourseWare Projects}

Distance education has a unique opportunity to deliver on the promise of the universal right to education. OpenCourseWares deliver high quality instructional content to an unlimited number of learners at virtually no additional cost beyond the original cost of production. Other tools are being developed that allow users to innovate with open educational content. Making educational content accessible beyond the walls of the original authoring institution can benefit everyone involved, including the reputation of the author and the institution itself.

Sustaining the OpenCourseWare movement has been a topic of conversation since the inception of the first OCW project. By 2005, the William and Flora Hewlett Foundation has granted in excess of $\$ 40$ million to support Open Educational Resources (Hewlett, 2005), but private foundation money is not the answer to long term sustainability. Downes (2007) suggested thinking beyond funding models.

[I]t also seems clear that the sustainability of OERs - in a fashion that renders then at once both affordable and usable - requires that we think of OERs as only part of a larger picture, one that includes volunteers and incentives, community and partnerships, co-production and sharing, distributed management and control. (p. 41)

To be sustainable, OCW will have to look back to its roots in open source software - to a model where the community works together and principles of openness and sharing guide the development of technologies, content, and financial support. "Everyone has the right to education (United Nations, 1948)." It has been almost 60 years since Article 26 of the Universal Declaration of Human Rights was written, and still we fall short of this assertion. And the role of distance education is shifting. "Now we live in a different world, for the first time. All the basic 
knowledge, all the refined physics, all the deep mathematics, everything of beauty in music, in the visual arts, all of literature, all of the video arts of the twentieth century can be given to everybody everywhere at essentially no additional cost beyond the cost it required to make the first copy" (Moglen, 2006). Now we have legal and technical tools to convert distance education materials into open education resources. For the first time, we can now begin to convert a 60year-old declaration into a reality.

\section{References}

Creative Commons (2007a). History: "Some rights reserved." Building a layer of reasonable copyright. Creative Commons. Retrieved November 17, 2007 from:

http://wiki.creativecommons.org/History

Creative Commons (2007b). About - Creative Commons. Retrieved November 29, 2007 from: http://creativecommons.org/about/

Downes, S. (2007). Models for sustainable open educational resources. Interdisciplinary Journal of Knowledge and Learning Objects, 3. Retrieved November 26, 2007 from: http://www.ijklo.org/Volume3/IJKLOv3p029-044Downes.pdf

Hewlett (2005). Open Educational Resources Initiative Overview. William and Flora Hewlett Foundation. Retrieved November 15, 2007 from: http://www.hewlett.org/Programs/Education/OER/Publications/oeroverview.htm

Kirkpatrick, K. L. (2006). OpenCourseWare. Searcher 14(6), p. 53-58.

MIT (2001). MIT to make nearly all course materials available free on the World Wide Web. Retrieved November 29, 2007 from: http://web.mit.edu/newsoffice/2001/ocw.html

MIT (2006). 2005 Program Evaluation Findings Report. Press Kit. Retrieved November 29, 2007 from: http://ocw.mit.edu/ans7870/global/05_Prog_Eval_Report_Final.pdf

MIT (2007a). MIT Marks OpenCourseWare Milestone. November 2007 Newsletter. Retrieved November 29, 2007 from: http://ocw.mit.edu/OcwWeb/web/about/newsletter/newsletternov07/newsletternov07.htm

MIT (2007b). Profiles: From diving to surfing. Retrieved June 7, 2007 from: http://www.ocw.cn/OcwWeb/Global/AboutOCW/profiles.htm

Moglen, E. (2006). Software and Community in the Early 21st Century. Retrieved January 30, 2007 from:

http://en.wikisource.org/wiki/Software_and_Community_in_the_Early_21st_Century

OCW Consortium (2007). About us. Retrieved February 6, 2008 from:

http://www.ocwconsortium.org/index.php?option=com content\&task=view\&id=15\&Ite $\underline{\operatorname{mid}=29}$

Stallman, R. (1983). Initial Announcement. GNU's Not Unix! Free Software, Free Community. Retrieved November 15, 2007 from: http://www.gnu.org/gnu/initial-announcement.html 
United Nations General Assembly (1948). Universal Declaration of Human Rights. Retrieved January 30, 2007 from:

http://en.wikisource.org/wiki/Universal_Declaration_of_Human_Rights\#Article_26

Utah OpenCourseWare Alliance (2007). Utah OpenCourseWare Alliance Home Page. Retrieved November 28, 2007 from: http://uocwa.org/

Wiley, D. A. (2003). A modest history of OpenCourseWare. Autounfocus blog. Retrieved November 20, 2007 from: http://www.reusability.org/blogs/david/archives/000044.html

Wiley, D. A. (2006). About COSL. Center for Open and Sustainable Learning. Retrieved November 1, 2007 from: http://cosl.usu.edu/about/?searchterm=COSL

Wikipedia (2007a). Wikipedia:About. Wikipedia, the Free Encyclopedia. Retrieved November 17, 2007 from: http://en.wikipedia.org/wiki/Wikipedia:About

Wikipedia (2007b). Richard Stallman contribution. Wikipedia, the Free Encyclopedia. Retrieved November 20, 2007 from: http://en.wikipedia.org/wiki/Richard_Stallman

Yue, K. B., Yang, T. A., Ding, W., Chen, P. (2004). Open courseware and computer science education. Journal of Computing Sciences in Colleges, 20(1), 178-186. Retrieved November 21, 2007 from: http://portal.acm.org/citation.cfm?id=1040255

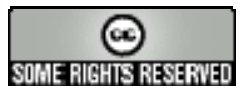

